\title{
Pengaruh Tetes Tebu dan Limbah Cair Tahu pada Produksi Biogas
}

\author{
Prasetiono* dan Triwikantoro \\ Jurusan Fisika-FMIPA, Institut Teknologi Sepuluh Nopember \\ Kampus ITS Sukolilo, Surabaya 61111
}

\begin{abstract}
Intisari
Metana adalah salah satu komponen gas terbesar dari produksi biogas yang dapat dimanfaatkan sebagai sumber energi. Peningkatan produksi biogas dilakukan salah satunya dengan memberikan bahan tambahan berupa tetes tebu dan limbah cair tahu pada kotoran sapi. Kotoran sapi dan bahan tambahan dicampur air dengan perbandingan massa $1: 2$, sedangkan perbandingan kotoran sapi dengan bahan tambahan dibuat secara bervariasi yaitu (90:10):2, (80:20):2 dan (70:30):2. Kandungan gas metana yang berada di tandon gas dideteksi pada hari ke-7 dan hari ke-20. Analisis produksi biogas menunjukkan bahwa awalnya penambahan tetes tebu dan limbah cair tahu menaikkan $\mathrm{CH}_{4}$, tetapi semakin besar jumlah tetes tebu yang ditambahkan semakin turun jumlah $\mathrm{CH}_{4}$ yang dihasilkan, sedangkan penambahan limbah cair tahu berpengaruh sebaliknya yaitu semakin besar tambahan limbah tahu, maka semakin besar produksi $\mathrm{CH}_{4}$.
\end{abstract}

KATA KUNCI: metana, tetes tebu, limbah cair tahu, biogas

\section{PENDAHULUAN}

Biogas merupakan salah satu alternatif pilihan yang dapat digunakan sebagai solusi mengatasi krisis bahan bakar. Tujuan dari penelitian adalah untuk mengetahui pengaruh bahan tambahan tetes tebu dan limbah cair tahu dalam produksi biogas. Batasan penelitian ini adalah menggunakan digester skala labaratorium yang terbuat dari galon air isi ulang 19 liter. Bahan kotoran sapi dan bahan tambahan berasal dari satu tempat khusus dan peternakan tertentu. Kotoran sapi berasal dari peternakan sapi perah yang bahan makanan utama berupa kosentrat. Bahan tambahan limbah cair tahu yang berasal dari jenis tahu tawar dan tetes tebu hasil limbah pabrik gula. Bahan tambahan tidak sebagai katalis tapi ikut bercampur dan bereaksi, sedangkan tekanan udara luar $1 \mathrm{~atm}$.

\section{DASAR TEORI}

\section{Proses Biogas}

Tahap hidrolisis, bahan organik dienzimatik secara eksternal oleh enzim ekstraseluler (selulosa, amylase, protease dan lipase). Bakteri memutuskan senyawa rantai panjang karbohidrat, protein dan lipida menjadi senyawa rantai pendek. Tahap pengasaman, tahap ini bakteri menghasilkan asam, mengubah senyawa rantai pendek hasil proses pada tahap hidrolisis menjadi asam asetat $\left(\mathrm{CH}_{3} \mathrm{COOH}\right)$, hydrogen $\left(\mathrm{H}_{2}\right)$ dan karbondioksida $\left(\mathrm{CO}_{2}\right)$. Bakteri tersebut merupakan bakteri anaerobik yang dapat tumbuh dan berkembang

*E-MAIL: prasetio_fisika@yahoo.com pada keadaan asam. Untuk menghasilkan asam asetat, bakteri tersebut memerlukan oksigen dan karbon yang diperoleh dari oksigen yang terlarut dalam larutan. Pembentukan asam pada kondisi anaerobik tersebut penting untuk pembentuk gas metana oleh mikroorganisme. Selain itu bakteri tersebut juga mengubah senyawa yang bermolekul rendah menjadi alkohol, asam organik, asam amino, karbondioksida, hydrogen sulfide, dan sedikit gas metana [1]. Tahap pembentukan metana, tahap ini bakteri metanogenik mendekomposisikan senyawa dengan berat molekul rendah menjadi senyawa dengan berat molekul tinggi. Bakteri pembentuk asam (acidogenic bacteria) yang merombak senyawa organik menjadi senyawa yang lebih sederhana, yaitu berupa asam organik, $\mathrm{CO}_{2}, \mathrm{H}_{2}$, dan $\mathrm{H}_{2} \mathrm{~S}$. Bakteri pembentuk asetat (acetogenic bacteria) yang merubah asam organik, dan senyawa netral yang lebih besar dari methanol menjadi asetat dan hydrogen. Bakteri penghasil metan (metanogens), yang berperan dalam merubah asam lemak dan alkohol menjadi metan dan karbondioksida.

\section{Faktor pembentukan biogas}

1. Nilai $\mathrm{pH}$ $\mathrm{pH}$ paling optimal berada pada $6,8-7,8$ [2].

2. temperatur, produksi biogas akan menurun secara cepat akibat perubahan temperatur yang mendadak. Bakteri perombak akan bekerja sangat baik pada temperatur $25-28^{\circ} \mathrm{C}$ [2].

3. Racun,

racun dapat membunuh bakteri dan dapat menyebabkan produksi biogas menurun bahkan tidak terjadi.

4. Sifat dari substrat, substrat yang berasal dari kotoran ternak merupakan substrat yang paling mudah digunakan dalam produksi 


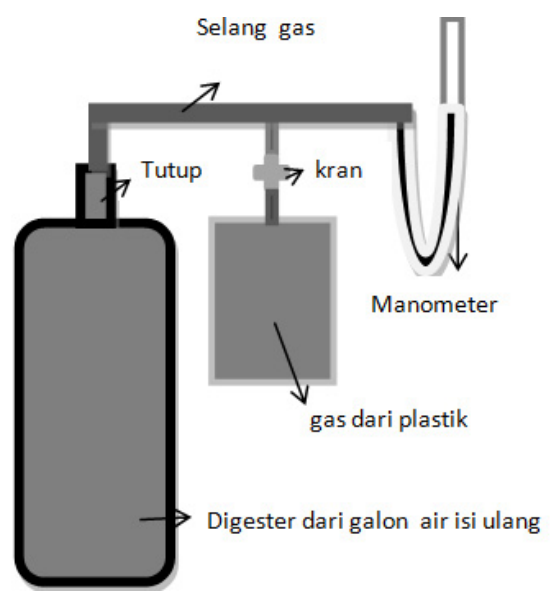

Gambar 1: Peralatan.

biogas dibandingkan substrat yang berasal dari tumbuhan.

\section{Limbah Cair Tahu dan Tetes Tebu}

Proses produksi tahu menghasilkan 2 jenis limbah, limbah padat dan limbah cairan. Banyak pabrik tahu skala rumah tangga di Indonesia tidak memiliki proses pengolahan limbah cair. Pada umumnya, biogas mengandung (50-80)\% metana $\left(\mathrm{CH}_{4}\right), \mathrm{CO}_{2}, \mathrm{H}_{2} \mathrm{~S}$ dan sedikit air, yang bisa dijadikan sebagai pengganti minyak tanah atau LPG. Air limbah industri tahu mempunyai kandungan metana lebih dari 50\% sehingga sangat memungkinkan untuk bahan sumber energi biogas.

Tetes tebu (molasses) merupakan produk sisa pada proses pembuatan gula. Tetes tebu diperoleh dari hasil pemisahan sirop low grade yang mana gula dalam sirop tersebut tidak dapat dikristalkan lagi.

\section{METODOLOGI PENELITIAN}

Alat yang digunakan tabung digester skala laboratorium dengan memanfaatkan galon air isi ulang, manometer air, termometer, $\mathrm{pH}$ meter/kertas dan selang gas yang dibuat seperti pada Gambar 1.

Kotoran sapi dan bahan tambahan dicampur dengan air dengan perbandingan 1:2, kemudian diaduk dengan sistem blending selama 5 menit dan dimasukan dalam digester dengan komposisi massa seperti pada Tabel I.

\section{HASIL DAN DISKUSI}

Untuk memperoleh hasil gas yang kontinyu, maka penelitian dilakukan terhadap 2 digester sekaligus yaitu degister untuk 1-7 hari dan digester untuk 1-20 hari. Hal ini sesuai dengan fase biogas yaitu fase inkubasi (sekitar 7 hari) dan fase stasioner (sekitar 20 hari). Sebelum bahan dimasukkan ke dalam tabung digester terlebih dahulu bahan dikarakterisasi
TABEL I: Perbandingan massa bahan tambahan

\begin{tabular}{lcccc}
\hline \hline $\begin{array}{l}\text { No } \\
\text { Sampel }\end{array}$ & $\begin{array}{c}\text { Kotoran } \\
\text { sapi(gram) }\end{array}$ & $\begin{array}{c}\text { Tetes } \\
\text { Tebu }(\text { gram })\end{array}$ & $\begin{array}{c}\text { Limbah cair } \\
\text { tahu(gram) }\end{array}$ & $\begin{array}{c}\text { Air } \\
\text { (gram) }\end{array}$ \\
\hline 1. & 4000 & - & - & 8000 \\
2. & 3600 & 400 & - & 8000 \\
3. & 3200 & 800 & - & 8000 \\
4. & 2800 & 1200 & - & 8000 \\
5. & 3600 & - & 400 & 8000 \\
6. & 3200 & - & 800 & 8000 \\
7. & 2800 & - & 1200 & 8000 \\
8. & 2400 & 400 & 400 & 8000 \\
\hline \hline
\end{tabular}

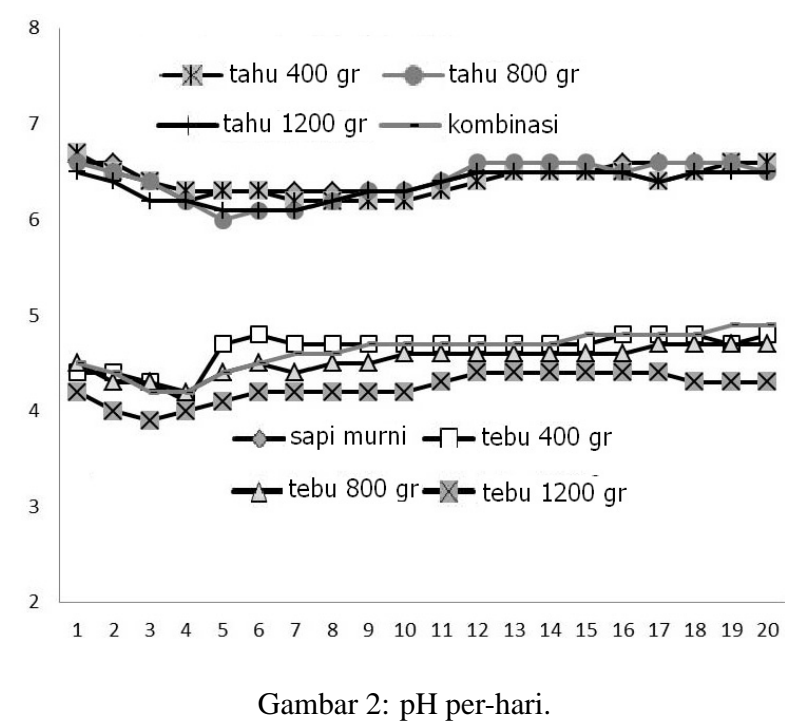

kandungan karbohidrat, protein, glukosa, karbon dan nitrogen. Hal ini penting karena kandungan bahan biogas yang berbeda akan menghasilkan kadar biogas yang berbeda. Nilai pH tiap digester dapat dilihat pada Gambar 2.

Nilai $\mathrm{pH}$ tetes tebu berkisar 4,0 - 4,9 sedangkan $\mathrm{pH}$ limbah cair tahu sekitar 6,2 - 6,8. Bahan kombinasi kotoran sapi, tetes tebu dan limbah cair tahu $\mathrm{pH}$-nya juga cenderung menuju asam yaitu sekitar 4,5 - 4,8. Nilai pH yang asam dapat menghambat produksi biogas. Hasil pengamatan selama 20 hari menunjukkan bahwa temperatur berkisar $(28-31)^{\circ} \mathrm{C}$, artinya temperatur tidak mengalami perubahan secara cepat, karena digester dikondisikan se-anaerob mungkin. Perubahan temperatur yang mendadak dapat menurunkan produksi biogas [2]. Tinggi manometer menunjukkan bahwa pada digester telah terbentuk gas baru, hal ini dapat dihitung tekanan gas yang terbentuk secara sederhana menggunakan manometer terbuka pipa u dengan persamaan: $\mathbf{P}=\mathbf{P}_{o}+\rho \mathbf{g h}$.

Hari ke-1 tidak ada perubahan tinggi manometer, artinya dalam digester belum terbentuk gas, sehingga tekanan yang ada merupakan tekanan udara luar sebesar 1 atm. Hari ke-2 hingga ke-7, tinggi manometer mulai meningkat, pada proses ini reaksi masih menggunakan oksigen yang berada dalam digester. Saat oksigen didalam digester mulai habis, maka proses pembentukan gas metana terjadi secara anaerob yaitu hari ke-7 hingga ke-20 (Gambar 3, 4, 5). Perhitungan tekanan gas dapat digunakan untuk menghitung perubahan jumlah mol 


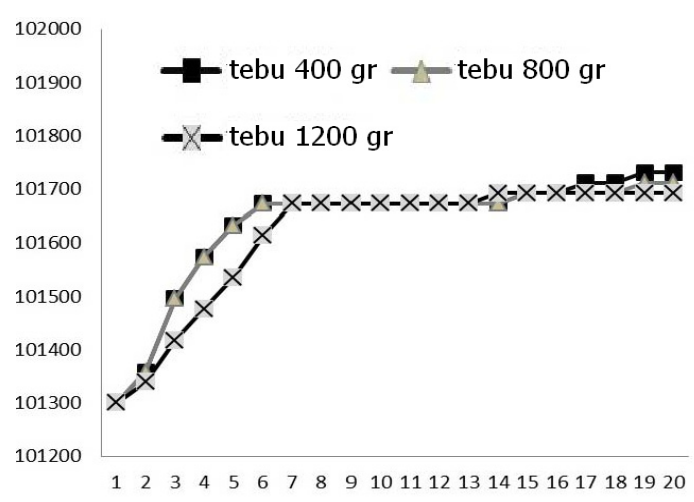

Gambar 3: Tekanan pada digester tetes tebu.

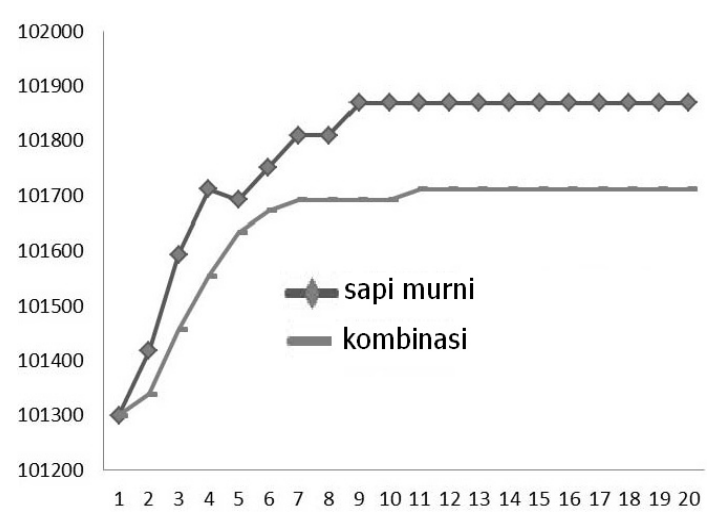

Gambar 4: Tekanan pada digester kotoran sapi murni dan tekanan digester kombinasi (kotoran sapi, tetes tebu, limbah cair tahu).

gas dengan persamaan: $\mathbf{P V}=\mathbf{n R T}$.

Kenaikan jumlah mol dapat diartikan adanya penambahan gas pada digester setiap harinya. Pada rentang 1 - 7 hari terjadi peningkatan jumlah mol yang cepat, kemudian pada hari 7 20 hari relatif stabil karena pada fase ini produksi gas metana mulai terbentuk (Gambar 6, 7, 8). Hasil akhir dari penelitian ini adalah menguji kadar gas metana yang terbentuk pada hari ke-7 dan hari ke-20 dengan menggunakan uji kromatografi.

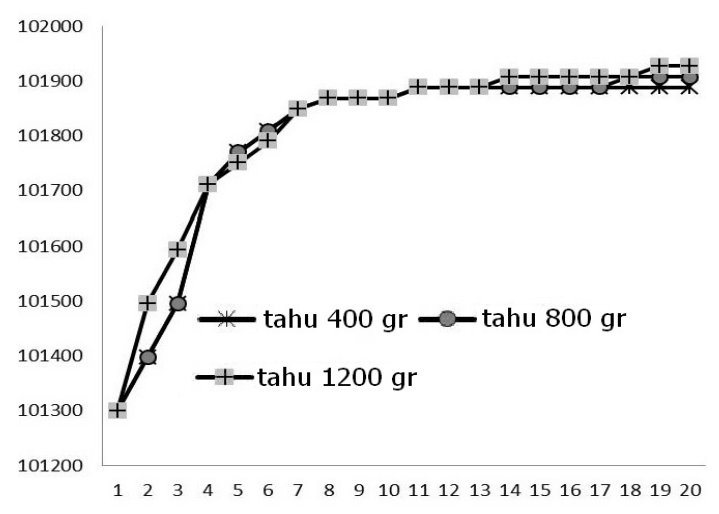

Gambar 5: Tekanan pada digester limbah cair tahu

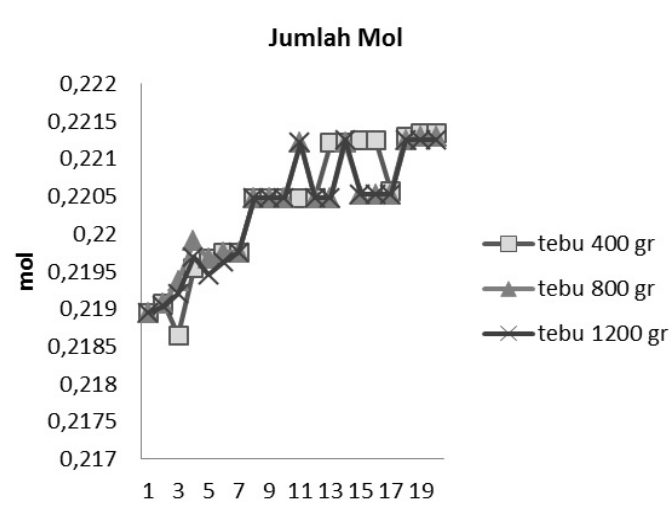

Gambar 6: Jumlah mol digester tetes tebu

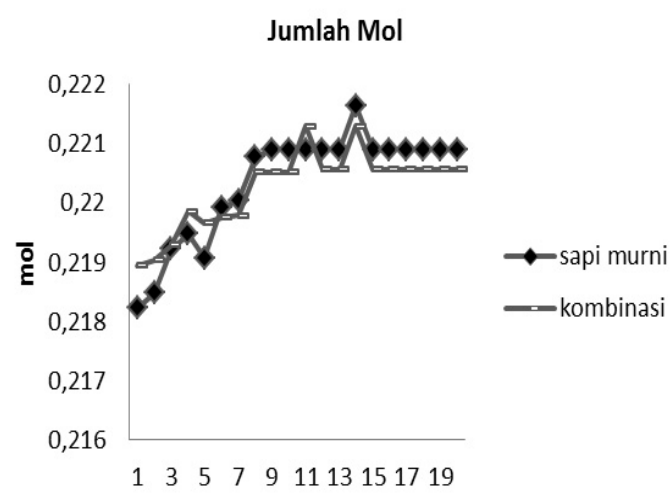

Gambar 7: Jumlah mol digester kotoran sapi murni dan jumlah mol digester kombinasi (kotoran sapi, tetes tebu, limbah cair tahu)

Hasil uji kromatografi dapat dilihat di Tabel II.

Kadar gas metana pada kotoran sapi murni sebesar 4821,94 ppm. Untuk tetes tebu, kadar gas metana terbesar terjadi pada komposis tetes tebu 400 gram yaitu sebesar 32385,5 ppm dan gas metan bahan tambahan limbah cair tahu terbesar pada komposisi 1200 gram adalah 73514,3 ppm.

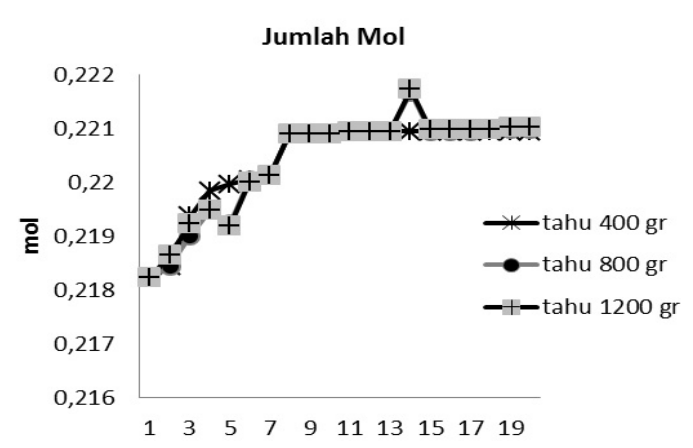

Gambar 8: Jumlah mol digester limbah cair tahu 
TABEL II: Kadar metana tiap digester

\begin{tabular}{lccc}
\hline \hline Sampel & $\begin{array}{c}\text { Kadar Metana } \\
\text { hari ke-7 }(\mathrm{ppm})\end{array}$ & $\begin{array}{c}\text { Kadar Metana } \\
\text { hari ke-20 }(\mathrm{ppm})\end{array}$ & $\begin{array}{c}\Delta \text { Kadar } \\
\mathrm{CH}_{4}(\mathrm{ppm})\end{array}$ \\
\hline Sapi murni & 8,76 & 4821,94 & 4813,18 \\
Tebu 400 gr & 2720,01 & 32385,5 & 29665,49 \\
Tebu 800gr & 443,43 & 27661,8 & 27218,37 \\
Tebu 1200gr & 192,08 & 5127,9 & 4935,82 \\
Tahu 400 gr & 2807,08 & 40704,0 & 37896,92 \\
Tahu 800 gr & 3002,54 & 53288,7 & 50286,16 \\
Tahu 1200gr & 4312,87 & 73514,3 & 69201,43 \\
Kombinasi & 2397,88 & 17310,5 & 14912,62 \\
\hline \hline
\end{tabular}

\section{SIMPULAN}

Tetes tebu dan limbah cair tahu berpengaruh pada produksi biogas. Penambahan limbah cair tahu komposi 400 gr, 800 gr dan 1200 gr meningkatkan produksi biogas sebesar 40704,0 ppm, 53288,7 ppm dan 73514,3 ppm, sedangkan penambahan tetes tebu pada kotoran sapi menyebabkan produksi biogas menurun yang dikarenakan tetes tebu semakin asam.

Pengembangan dan penelitian selanjutnya dapat dibuat kombinasi perbandingan bahan tambahan : air $=1: 1$ dan komposisi perbandingan massa tambahan yang berbeda.
[1] K. Amaru, Rancang Bangun dan Uji Kinerja Biodigester Plastik Polyethilene Skala Kecil (Studi Kasus Ds. Cidatar Kec. Cisurupan, Kab. garut), Tugas Akhir, Fakultas Pertanian, UNPAD, Indonesia, 2004.

[2] S.Simamora, dkk., Membuat Biogas Pengganti Bahan Bakar Minyak dan Gas (Agro Media Pustaka, Jakarta, 2006).

[3] V. Darsono, Jurnal Teknologi Industri, XI, no. 1, 9, (2007).

[4] Desniar, Buletin Teknologi Hasil Perikanan, VII, no.1, 26, (2004).

[5] T. Sullavan, Biogas Digester (Department of engineering and Surveying University of Southern Queensland, 2007).
[6] Daryanto, Energi (Pustaka widyatama, Yogyakarta, 2007).

[7] S.H. Ginting, dkk, Dasar-dasar Teknologi Biogas (PTP: ITB, Bandung, 1978).

[8] E.C. Daugherty, Biomass Energy Systems Efficiency:Analyzed through a Life Cycle Assessment, (Lund Univesity, Sweden, 2005).

[9] T. Haryati, Artazoa, 16, no.3, 160, (2006).

[10] L. Cahyaningrat, Pemurnian Produk Biogas dengan Metode Filtering menggunakan $\mathrm{CaO}$ dan anoda karbon (paduan $\mathrm{Zn}$, Serbuk Fe), Tugas Akhir Fisika FMIPA, ITS, Surabaya, 2007. 